\title{
The Correlation between Hamstring Tightness and Plantar Fasciitis
}

\author{
MOHAMED A. SAYED, M.Sc.*; SALWA FADL ABD EL-MEGID, Ph.D.*; HATEM M. EL-AZIZY, M.D.** and \\ HAMED M. EL-KHOZAMY, Ph.D.* \\ The Department of Physical Therapy for Musculoskeletal Disorders and its Surgery, Faculty of Physical Therapy*and \\ The Department of Radiology, Faculty of Medicine**, Cairo University
}

\begin{abstract}
Background: A significant number of individuals suffer from pain in the heel and many go on to have chronic symptoms and went to disability, and it may affect sedentary and active adults of all ages. Active knee extension test (AKE) is commonly used to assess flexibility and length of the hamstring muscles that's may be related to plantar fasciitis.
\end{abstract}

Aim of Study: To assess the relationship between hamstring tightness and plantar fasciitis.

Subjects and Methods: Thirty patients who were coming complaining of heel pain, their age ranged from 30-50 years. All participants were asked to assess plantar fascia thickness by ultrasonoghraphy and to assess hamstring length by range of active knee extension test; aiming to detect the correlation between hamstring tightness and plantar fasciitis. The mean age was $39.72 \pm 5.58$ years (range: $31-48$ years), $83.3 \%$ were female, $66.6 \%$ were affected bilaterally and the mean BMI was $28.94 \pm 2.94 \mathrm{Kg} / \mathrm{m}^{2}$

Results: There is a strong negative linear correlation between the thickness of plantar fasciitis and range of active knee extension test. This means that any increase in the thickness of plantar fasciitis, will be associated with decrease in active knee extension angle.

Conclusions: There is a strong correlation between plantar fasciitis and hamstring tightness.

Key Words: Plantar fasciitis - Plantar fascia - Hamstring tightness - Active knee extension test.

\section{Introduction}

THE plantar fascia is a very important connective tissue structure in maintaining the longitudinal arch of the foot [1]. It occupies almost the whole length of the plantar aspect of the foot from calcaneus to metatarsal heads [2].

Correspondence to: Dr. Mohamed A. Sayed,

The Department of Physical Therapy for Musculoskeletal Disorders and its Surgery, Faculty of Physical Therapy, Cairo University
Plantar fasciitis is one of the most common causes of heel pain [1]. About $80 \%$ of all heel pain cases are caused by plantar fasciitis [3]. It affects about $10 \%$ of world wide populations [4].

Incidence of plantar fasciitis in patients with hamstring tightness is 8.7 times if compared with patients without hamstring tightness [5].

The exact cause of plantar fasciitis is not clear [6]. However the most accepted theory about its etiology is that the repeated stress to plantar fascia leads to micro trauma and chronic inflammation, leads to stiffness in the fascia and makes it more prone to re-injury [7] .

Plantar fasciitis is also called by many other names such as: Heel spur syndrome, runner's heel, subcalcaneal pain and calcaneodynia $[8]$.

It can be diagnosed clinically depending on patient's symptoms and physician's examination [9]. The most common symptom is heel pain after a long period of non weight bearing such as in the morning after rising from bed or after standing up from a long period of seating [10]. The most common sign that can be elicited by physician is pain by palpation of inferior heel (site of planter fascia) [11].

The main lines of its treatment are patient education as it is a self limiting condition that resolves spontaneously in $95 \%$ of patients in 12 18 months [8], physiotherapy; the stretching exercises to stretch the plantar fascia and Achilles tendon so that the stress on the plantar fascia can be relieved [12] and orthotic shoes to decrease strain on the fascia by elevating the heel and providing support to the medial arch of the foot [13], others: Application of ice and heat, soft tissue massage, night splint, chiropractic therapy, electric 
modalities, acupuncture and taping [3], extracorporeal shock wave therapy can be used if failed non surgical treatment for 6 months [14], medication; corticosteroid injection [15] and oral NSAIDs [16] and surgical intervention; partial plantar fasciotomy is rarely indicated [3]

\section{Subjects and Methods}

\section{Selection of cases:}

This non causal correlation study was conducted in Physical Therapy Outpatient Clinics, in Faculty of Physical Therapy and in Faculty of Medicine, Cairo University from January to June 2018.

\section{Inclusion criteria:}

Patients were diagnosed as plantar fasciitis (unilateral or bilateral) according to the following clinical manifestations:

- Patients diagnosis as plantar fasciitis by ultrasonography which show reducing in echogenecity and increase in thickness of the fascia $>4 \mathrm{~mm}$.

- Chronic manifestation at least 3 months.

\section{Exclusion criteria:}

- Subjects who have osteoarticular pathology in the hip, knee and ankle that causing pain or restricted movement.

- Disorders related to heel pain, such as subcalcaneal bursitis, Achilles tendon bursitis, Haglund's exostosis, or fracture of the calcaneus.

- History of recent trauma to the lower limbs or elective surgery. Specifically, subjects were excluded from the study group if they had been treated for plantar fasciitis with muscle stretching exercises or night splints, or who reported some direct trauma as being the origin of the plantar pain.

- Subject who have history of hamstring trauma or strain.

- Neurological pain that confused pain in lower limb as radiating pain from spinal problems.

\section{Ethical consideration:}

- Ethical approvals were obtained from the Research Committee in Faculty of Physical Therapy, Cairo University and the Ethical and Research Committee of Musculoskeletal Disorders and Surgery Department.

- The necessary official permission to carry out the study was obtained from the manager of outpatient clinics at Cairo University Hospitals.
- An informed written consent was taken from all patients after full explanation of nature of the study, benefits and possible harms of the study.

\section{Methods:}

A universal goniometer was used to measure the popliteal angle of the knee for hamstring length measurements while the hip was maintained at 90 degrees of flexion. The universal goniometer have an excellent intrarater reliability (ICC=.74-.99) [3]

Ultrasonography was used to confirm the diagnosis of plantar fasciitis and to measure plantar fascia thickness, and echogencity of its proximal part. The thickness of the plantar fascia will measured at its proximal end near its insertion into the calcaneus $(1 \mathrm{~cm}$ away from the insertion point to the bone). The ultrasonography was done in Kaser Al-Ainy Hospital Radiology Department by Toshiba aplio 500 sonar device using small parts head Fig. (1). The AKE was performed using an experimental apparatus designed for the patients who had plantar fasciitis. It consists of a rectangular wooden frame that was fixed to an examination table. Participants lay in the supine position on the table, facing the wooden apparatus. The tested limb was flexed until the thigh touched the wooden apparatus, being at $90^{\circ}$ vertical on the table. The contra lateral limb was fully extended and stabilized in neutral position by the belt Fig. (2).

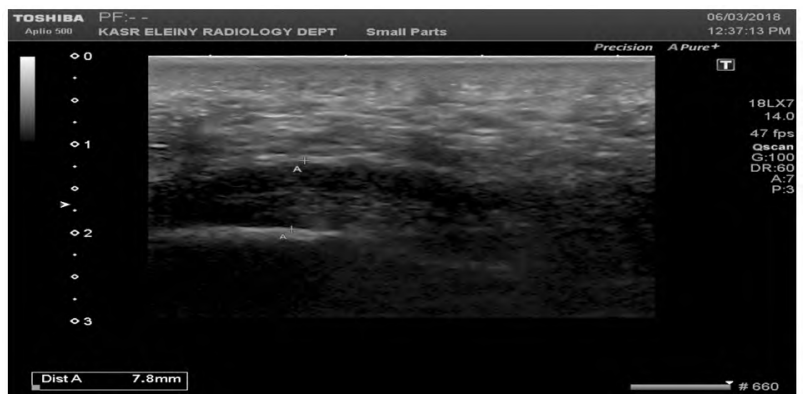

Fig. (1): Ultrasonography for measuring planter fascia thickness.

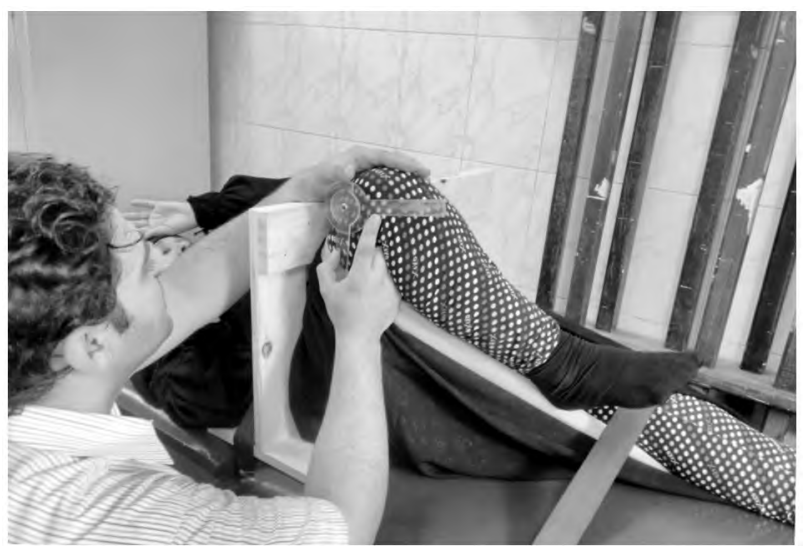

Fig. (2): Active knee extension test. 
A standard universal goniometer was placed over the lateral femoral condyle, with 1 arm aligned along the thigh in direction to the greater trochanter and the other arm aligned over the leg in the direction of the lateral malleolus.

From this position, and without any prior warmup, subjects were instructed to extend the knee until they felt a strong resistance then record the angle by the universal gonimeter. After the goniometric reading, the tested leg resumed the resting position for 1 minute, after which the same procedures were executed for two trials and the average was recorded.

\section{Statistical analysis:}

The association between the ultrasound results and the AKE results was examined using the Pearson product-moment correlation was used to determine the strength and direction of a linear correlation between thickness of plantar fasciitis and range of active knee extension test. The alpha level was set at 0.05. Using SPSS for windows, Version 23 (SPSS, Inc., Chicago, IL). Prior to final analysis, data were screened for normality assumption, linearity, and presence of extreme scores. This exploration was done as a pre-requisite for parametric calculations of the analysis of difference. There was a linear relationship between the dependent variables, as assessed by scatter plot. There were no univariate outliers in the data, as assessed by inspection of a box plot. Normality test of data using Shapiro-Wilk test was used, that reflect the data was normally distributed for both dependent variables $(p>0.05)$.

\section{Results}

A total of thirty patients (Table 1) suffered from heel pain recruited from faculty of physical therapy clinic and kasralainy hospital through announcements for volunteering to participate in noninvasive study their age ranged from $31-48(40 \pm 2.04)$ years.

The mean values of age, weight, height and Body Mass Index (BMI) were $39.72 \pm 5.58$ years, $78.52 \pm 11.64 \mathrm{~kg}, 165 \pm 8.91 \mathrm{~cm}$ and $28.94 \pm 2.94 \mathrm{Kg} / \mathrm{m}^{2}$ respectively as presented at (Table 2 ).

Pearson correlation coefficient $(r)$ between mean value of thickness of plantar fasciitis measured by ultrasonography and active knee extension angle was 0.613 . The results indicated that there was a negative strong correlation between mean value of thickness of plantar fasciitis and active knee extension angle $(p=0.0001)$. This means that increase in the thickness of plantar fasciitis is consistent with decrease in active knee extension angle (Table 3) and Fig. (3).

Table (1): Patients and feet with plantar fasciitis.

\begin{tabular}{lcc}
\hline & Patients $(\mathrm{N}=30)$ & Feet $(\mathrm{N}=50)$ \\
\hline Unilateral PF & 10 & 10 \\
Left foot & 6 & 6 \\
Right foot & 4 & 4 \\
Bilateral PF & 20 & 20 \\
\hline Total & 30 & 50 \\
\hline
\end{tabular}

Table (2): Physical characteristics of patients with plantar fasciitis.

\begin{tabular}{lllll}
\hline $\begin{array}{l}\text { Demographic } \\
\text { variables }\end{array}$ & Minimum & Maximum & Mean & $\begin{array}{c}\text {.td. } \\
\text { deviation }\end{array}$ \\
\hline Age & 31.00 & 48.00 & 39.7200 & 5.58438 \\
Height & 165.00 & 165.00 & 165.0000 & 8.91 \\
Weight & 63.00 & 110.00 & 78.5200 & 11.64131 \\
BMI & 25.20 & 34.80 & 28.9440 & 2.94016 \\
\hline
\end{tabular}

Table (3): Correlation between thicknesses of plantar fascia measured by ultrasonography and active knee extension angle.

\begin{tabular}{lcc}
\hline & $\begin{array}{c}\text { Thickness of } \\
\text { plantar fasciitis }\end{array}$ & $\begin{array}{c}\text { Active knee } \\
\text { extension angle }\end{array}$ \\
\hline Mean \pm SD & $5.37 \pm 1.11$ & $131.32 \pm 11.22$ \\
$r$ & -0.613 & \\
$p$-value & $0.0001 *$ & \\
\hline
\end{tabular}

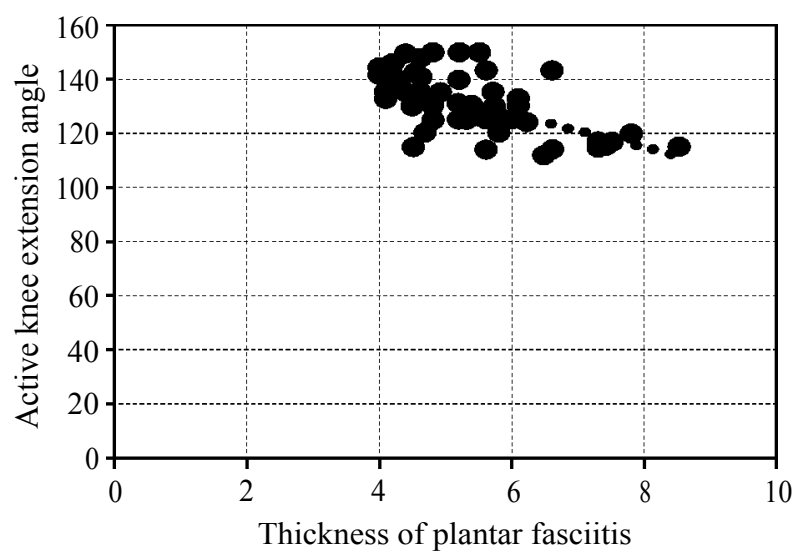

Fig. (3): Scatter plot for the bivariate correlation between thickness of plantar fasciitis measured by ultrasonography and active knee extension angle.

\section{Discussion}

In this study 50 persons had the typical symptoms of plantar fasciitis who would took to make to them ultrasonoghraphy but only thirty adults patients ( 25 female and 5 male) their results were more than $4 \mathrm{~mm}$ acted as study group represent 
plantar fasciitis the results of this study show that there is a significant reverse relationship between angle of knee extension in AKE and thickness of plantar fascia.

The results of current study support study of Labovitz [5] who observed that patients had hamstring tightness were about 8.7 times as likely to be plantar fasciitis patients [5]

And also the current study support study of Harty [17] who found that the increase in hamstring tightness may induce prolonged forefoot loading and through the windlass mechanism be a cause that increases repetitive injury to the plantar fascia [17].

Bolívar [18] found that; tightness of the posterior muscles of the lower limb was present in the plantar fasciitis patients, but not in the unaffected participants [18]

Smith [19] said that the thickened plantar fascia may be a cause of hamstring tightness and cervical and lumber lordosis [19].

Many patients have plantar fasciitis and pain in hamstring muscle due to tightness result from tension that caused by plantar fasciitis and transfer to hamstring muscle along the Superficial Back Line (SBL) [19].

The Superficial Back Line (SBL) connects and protects the entire posterior surface of the body like a carapace from the bottom of the foot to the top of the head in two pieces-toes to knees, and knees to brow when the knees are extended, as in standing, the SBL functions acts as one continuous line [19].

In many cases plantar fasciitis come first and the pain in the back of the thigh come second, so that in this condition plantar fasciitis should be treated firstly to relief hamstring tightness and pain.

The results of the current study showed that the plantar fasciitis is strongly associated with the hamstring tightness and should also be addressed in the treatment for the increasing in knee extension occurs that's may be the cause of plantar fasciitis.

\section{Conclusion:}

This study proved that plantar fasciitis is strongly associated with hamstring tightness, but it's design (non causal correlation) does not allow establishing any cause-effect relationship.

\section{References}

1- E.G. McNALLY and S. SHETTY: "Plantar fascia: Imaging diagnosis and guided treatment," Semin. Musculoskelet. Radiol., Vol. 14, No. 3, pp. 334-43, 2010.

2- M.A. MOHSENI-BANDPEI, M. NAKHAEE, M.E. MOUSAVI, A. SHAKOURIRAD, M.R. SAFARI and R. VAHAB KASHANI: "Application of ultrasound in the assessment of plantar fascia in patients with plantar fasciitis: A systematic review," Ultrasound Med. Biol., Vol. 40, No. 8, pp. 1737-54, 2014.

3- S. ATTAR: "Plantar Fasciitis: A Review Article," No. March 2012, 2014.

4- S.A. OGUNTONA and O.O. OGUNSEMI: "Plantar Fasciitis among Nigerians," Glob. Adv. Res. J. Med. Med. Sci., Vol. 2, No. 3, pp. 2315-5159, 2013.

5- J.M. LABOVITZ, J. YU and C. KIM: "The Role of Hamstring Tightness in Plantar Fasciitis," Foot Ankle Spec., Vol. 4, No. 3, pp. 141-4, 2011.

6- P. BEESON: "Plantar fasciopathy: Revisiting the risk factors," Foot Ankle Surg., Vol. 20, No. 3, pp. 160-5, 2014.

7- R.S. AHMED: "The Incorporation of Balancing Board Exercises in the Management of Plantar Fasciitis," Vol. 16, No. 1, pp. 19-28, 2011.

8- M.S. DAVIES, F.R.C.S. ORTH, G.A. WEISS, T.S. SAXBY and F.R.A.C.S. ORTH: "Plantar Fasciitis: How Successful Is Surgical Intervention?,” No. March 1992, 2012.

9- J. ORCHARD: "Plantar fasciitis," BMJ, Vol. 345, No. Oct. 10 1: pp. e6603-e6603, 2012.

10- J.D. GOFF, R. CRAWFORD and S.H. SYSTEM "Diagnosis and Treatment of Plantar Fasciitis," 2011.

11- J.L. THOMAS, et al.: "The Diagnosis and Treatment of Heel Pain: A Clinical Practice Guideline-Revision 2010," J. Foot Ankle Surg., Vol. 49, No. 3, 2010.

12- Y. MASTERS: "The effect of combining muscle energy technique with soft tissue massage on hamstring extensibility," pp. 1-102, 2014.

13- S.M. MCCLINTON, et al.: "Comparison of usual podiatric care and early physical therapy intervention for plantar heel pain: Study protocol for a parallel-group randomized clinical trial," pp. 1-9, 2013.

14- A. MS: "Is Extracorporeal Shock Wave Therapy an Underutilized Treatment for Chronic Plantar Fasciitis?," Vol. 44, Pp. 10-11, 2015.

15- C. KIM, M.R. CASHDOLLAR and R.W. MENDICINO: "Incidence of plantar fascia ruptures following corticosteroid injection.," Foot Ankle Spec., Vol. 3, No. 6, pp. 335-7, 2010.

16- N. MUSHTAQ, A. ABBASIAN, S. CUTTS, N. OBI, C. PASAPULA and W. CHAN: "Plantar fasciitis," Ann. R. Coll. Surg. Engl., Vol. 95, No. 3, pp. 229-229, 2013.

17-J. HARTY, K. SOFFE, G. O'TOOLE and M.M. STEPHENS: "The role of hamstring tightness in plantar fasciitis," Foot Ankle Int., Vol. 26, No. 12, pp. 1089-92, 2005.

18- Y.A. BOLÍVAR, P.V. MUNUERA and J.P. PADILLO: "Relationship between tightness of the posterior muscles of the lower limb and plantar fasciitis," Foot Ankle Int., Vol. 34, No. 1, pp. 42-8, 2013.

19- T.W. SMITH: “Anatomy Trains," Foot, Vol. 12, No. 4, p. 255,2002 


\section{العلا قة بين الشد العضلى للعضلة الخلفية للفخذ العادئ \\ وإلتهاب اللفافة الآخمصية الفية الفيل}

الخظفية: يعانى عدد كبير من الآفراد من آلام فى الكعب، وفى معظم الآحيان تحدث هذه آلام فى صورة مزمنة، وقد يتعرض هؤلاء الآفراجالى

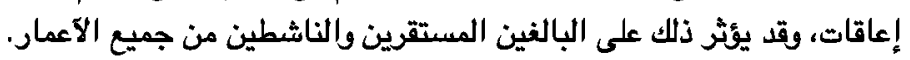

الغرض: تقييم العلاقة بين الشد العضلى اللعضلة الخلفية للفخذ وإلتهاب اللفافة الاخمصى.

عدد المشّاركين فى البحث: ثلاثون مريضا يعانفن من الآلم مزمنة بالكعب لمدة لا تقل عن ثلاثة شهود وأعمارهم تتراوح بين . بـ .0 عاما.

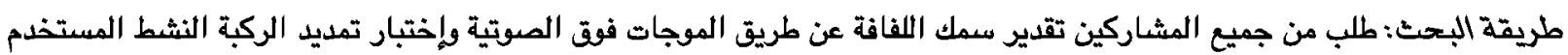

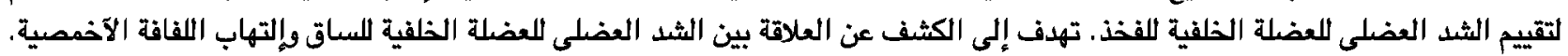

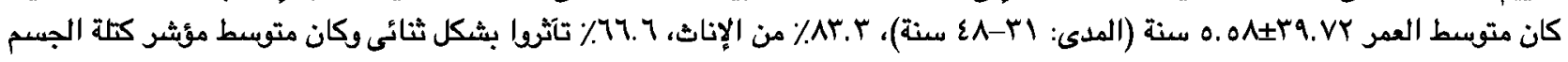

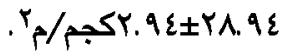

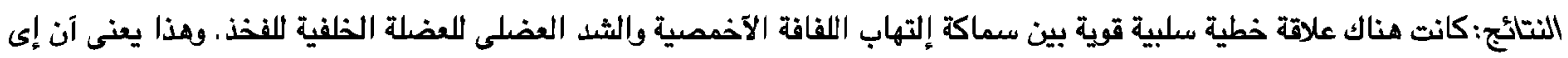

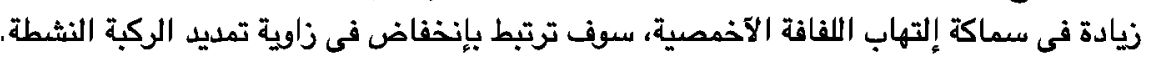
الإستستاجات:إرتباط إلتهاب اللفافة الآخمصية المرتبطة بشدة مع الشد العضلى للعضلة الخلفية للفخذ. 